\title{
Estimation of Natural Radioactivity of Some Medicinal or Herbal Plants Used in Kars, Turkey
}

\author{
Gülçin Bilgici Cengiz*, ilyas Çağlar² \\ 1 Kafkas University, Faculty of Arts and Sciences, Physics Department, Kars, Turkey \\ 2 Kafkas University, Kazım Karabekir Vocational School of Technical Sciences, Kars, Turkey
}

\begin{abstract}
In Natural radioactive materials may be existing in the environmental substances that have uses in pharmacy and medicine as health supplements. In this study, natural radionuclides such as ${ }^{226} \mathrm{Ra},{ }^{232} \mathrm{Th}$, and ${ }^{40} \mathrm{~K}$ were measured in seven medicinal or herbal plants collected from the local market in Kars, Turkey were analysed. All samples were analysed by means of gamma-ray spectrometer using $\mathrm{NaI}(\mathrm{Tl})$ detector. The radioactivity concentrations were found to vary in the range of $16.39 \pm 2.2$ to $32.76 \pm 3.5 \mathrm{Bqkg}^{-1}$ for ${ }^{226} \mathrm{Ra}, 19.74 \pm 3.7$ to $85.01 \pm 5.6 \mathrm{Bqkg}^{-1}$ for ${ }^{232} \mathrm{Th}$, and from $795.82 \pm 9.8$ to $1056.28 \pm 14.4 \mathrm{Bqkg}^{-1}$ for ${ }^{40} \mathrm{~K}$. Rosehip showed the lowest activity concentrations of ${ }^{226} \mathrm{Ra},{ }^{232} \mathrm{Th}$ and ${ }^{40} \mathrm{~K}$, while rumex patientia showed the highest activity concentration of ${ }^{40} \mathrm{~K}$. In this research study, we aimed to determine the activity concentrations of radionuclides in medicinal plants and provide useful information to carry out a dose assessment to be exposed to people using medicinal plants for healing various diseases.
\end{abstract}

Keywords: Kars, Medicinal Plants, Natural radionuclides, Activity concentration, Gamma Spectroscopy

\section{INTRODUCTION}

Since the beginning of human history, many plants have been used as nutrients and medicines. Today, some of the alternative medicine methods have been scientifically proven by pharmacists, medicine people and molecular biologists and reintroduced into the lives of people with the approval of the authorities ${ }^{1}$. The use of traditional herbal medicines for the treatment of various diseases makes it very important to determine the radionuclide concentrations

*Corresponding author: Gülçin Bilgici Cengiz, e-mail: gulcincengiz@kafkas.edu.tr Gülçin Bilgici Cengiz ORCID Number: 0000-0002-6164-3232

Illyas Çăglar ORCID Number: 0000-0002-6958-8469

(Received 07 August 2019, accepted 16 September 2019) 
in such plants ${ }^{2-4}$. Plants can be affected by radioactive substances in two basic ways. These are direct and indirect contamination. Direct contamination is the accumulation of atmospheric radionuclides in the above-ground parts of the plant. Indirect contamination is the absorption of radionuclides from the soil by the plants' root systems ${ }^{5,6}$. The extent to which roots absorb radionuclides from the soil does not only depend on their physiology but also on the processes within the soil 7 . The study of the concentration of radioactivity in plants in the environment is interesting in terms of ecological and plant development under certain geochemical point of view and adaptation conditions and therefore provides information in monitoring environmental radioactivity ${ }^{8,9,10}$. The aim of this study is to determine the natural radioactivity of some selected medicinal plants commonly used in Kars, Turkey and to evaluate the radiological risks associated with the use of these medicinal plants.

\section{METHODOLOGY}

Kars has the geographical coordinates $40^{\circ} 14^{\prime} 34^{\prime \prime}-40^{\circ} 84^{\prime} 38^{\prime \prime}$ North and $42^{\circ} 59^{\prime} 01^{\prime \prime}-43^{\circ} 62^{\prime} 08^{\prime \prime}$ East. At an altitude of 1768 meters above sea level, the city has plateaus, mountains and green spaces. The area of the city is 18557 $\mathrm{km}^{2}$ and as of 2018 the city population is 288878 .

Leaves, flowers and fruits in the form of $2 \mathrm{~kg}$ weight, seven medicinal plants were collected from various local markets in Kars. The samples were open-air dried in trays for one week and then oven dried at $100{ }^{\circ} \mathrm{C}$ for 2 to 4 hours in the laboratory. The dried samples were then pulverized with a blender and sieved through a $1 \mathrm{~mm}$ mesh to achieve homogeneity. The prepared samples were weighed into powder form and packaged in radon impervious plastic containers (2.5 inch in height and 3 inch in diameter) and encoded. The samples were stored for 40 days to provide balance between ${ }^{226} \mathrm{Ra},{ }^{232} \mathrm{Th}$ and their shortlived degradations ${ }^{11,12}$. Radioactivity measurements were performed by using $\mathrm{NaI}(\mathrm{Tl})$ detector based on gamma spectrometry system. The detector was shielded with a $5 \mathrm{~cm}$ thickness lead layer to reduce the background due to cosmic rays and radiation nearby the system. Before the measurements an empty plastic sample container was counted in the same manner as the samples for the determination of the background effects. The system was calibrated using a standard reference material (IAEA-375) prepared by IAEA. For determining the activity concentrations in the medicinal plant and herbal plant samples, suitable photopeaks at several energies were taken into account and the appropriate area (ROI) regions were selected for each peak. The activity concentrations of ${ }^{40} \mathrm{~K}$ was evaluated from the $1460.8 \mathrm{keV}$ gamma line. ${ }^{226} \mathrm{Ra}$ concentration was found out by measuring the $609.3,1120.3$ and $1764.5 \mathrm{keV}$ gamma-rays 
from ${ }^{214} \mathrm{Bi}$. Similarly, $583 \mathrm{keV}$ and $2614.5 \mathrm{keV}$ gamma-rays from ${ }^{208} \mathrm{Tl}$ were used to indicate the activity concentration of ${ }^{232} \mathrm{Th}$. The samples were counted for a period of $24 \mathrm{~h}$. The output of the detector was analysed using a MCA system connected to PC. Ortec Maestro software was used for analysing the gammaray spectra. After measurements and subtraction of the background, the activity concentrations were determined. The activity concentrations of the samples were determined from radionuclide's own energies or gamma-ray photopic of their decay products ${ }^{13}$.

The activity concentrations of the samples are calculated using the expression in equation (1)

$$
\mathrm{A}=\frac{A_{\text {Net }}}{\varepsilon_{\gamma} P_{\gamma} t_{c} M_{s}}
$$

where $A_{\text {Net }}$ corresponds the net peak area of gamma-ray energy, $\varepsilon \gamma$ denotes the absolute efficiency, $\mathrm{P} \gamma$ is the gamma-ray yield per decay, $\mathrm{t}_{\mathrm{c}}$ and $\mathrm{M}_{\mathrm{s}}$ denotes the counting time (s) and dry weight of sample (kg), respectively 9 .

\section{RESULTS AND DISCUSSION}

In this study, the activity concentrations of ${ }^{226} \mathrm{Ra},{ }^{232} \mathrm{Th}$ and ${ }^{40} \mathrm{~K}$ have been determined for 7 kinds of medicinal plants in a total of 20 samples. The range of radioactivity concentrations (in dry weight, Bqkg-1) of the natural radionuclides $\left({ }^{226} \mathrm{Ra},{ }^{232} \mathrm{Th}\right.$ and $\left.{ }^{40} \mathrm{~K}\right)$ in the selected medicinal plants are listed in Table 1. As can be seen from Table 1, the measured values of ${ }^{226} \mathrm{Ra}$ content range from 16.39 $\pm 2.2 \mathrm{Bqkg}-1$ (rosehip) to $32.76 \pm 3.0 \mathrm{Bqkg}-1$ (chamomile). The range of ${ }^{232} \mathrm{Th}$ content in the studied herbs is from 19.74 \pm 3.7 Bqkg-1 (rosehip) to $85.01 \pm 5.6 \mathrm{Bqkg}^{-1}$ (parsley). ${ }^{40} \mathrm{~K}\left(\mathrm{Bqkg}^{-1}\right)$ were ranged from $795.82 \pm 9.8$ in rosehip sample to $1056.28 \pm 14.2 \mathrm{Bqkg}^{-1}$ in patience dock sample. Rosehip had the lowest activity concentration of ${ }^{226} \mathrm{Ra},{ }^{232} \mathrm{Th}$ and ${ }^{40} \mathrm{~K}$, while patience dock had the highest activity concentration of ${ }^{40} \mathrm{~K}$. 
Table 1. Activity concentrations of the studied medicinal plant samples.

\begin{tabular}{|c|c|c|c|c|}
\hline \multirow{2}{*}{ Common name } & \multirow{2}{*}{ Scientific name } & \multicolumn{3}{|c|}{ Average of activity concentration $\left(\mathbf{i n ~} \mathbf{B q} \mathbf{~ k g}^{-1}\right.$ ) } \\
\cline { 3 - 5 } & Rumex patentia & $1056.28 \pm 14.2$ & $53.09 \pm 3.2$ & $17.99 \pm 3.2$ \\
\hline Patience dock & ${ }^{40} \mathbf{K}$ & ${ }^{232} \mathbf{T h}$ & $22.82 \pm 3.4$ \\
\hline Stinging nettle & Urtica dioica & $999.68 \pm 15.0$ & $59.36 \pm 4.0$ & $27.45 \pm 5.2$ \\
\hline Thyme & Thymus & $828.30 \pm 9.2$ & $60.98 \pm 4.2$ & $16.39 \pm 2.2$ \\
\hline Rosehip & Rosa canina L. & $795.82 \pm 9.8$ & $19.74 \pm 3.7$ & $21.03 \pm 4.1$ \\
\hline Parsley & $\begin{array}{c}\text { Petroselinum } \\
\text { sativum }\end{array}$ & $949.23 \pm 15.2$ & $85.01 \pm 5.6$ & $20.22 \pm 3.2$ \\
\hline Mint & $\begin{array}{c}\text { Mentha longifo- } \\
\text { lia L. }\end{array}$ & $934.87 \pm 16.3$ & $64.26 \pm 4.1$ & $32.76 \pm 3.5$ \\
\hline Chamomile & $\begin{array}{c}\text { Matricaria chamo- } \\
\text { milla L. }\end{array}$ & $965.20 \pm 18.2$ & $84.82 \pm 5.2$ & \\
\hline
\end{tabular}

The high activity potassium concentration recorded for patience dock samples may be due to potassium-rich fertilization in the soil where it grows. Differences in activity concentrations may be due to differences in the geological location of plants and the radiochemical composition of the soils where these medicinal plants are grown or planted. Even in plants grown in the same region, the activity concentration levels of natural radionuclides may vary because some plants also absorb certain elements more than others 9 .

The important factors that affect the natural radionuclide levels in the studied medicinal plants are their different origins, the plant transfer factors and the levels of radionuclides in different edible portions. For these reasons, the levels of naturally occurring radionuclides have wide ranges. The concentrations of ${ }^{226} \mathrm{Ra},{ }^{232} \mathrm{Th}$ and ${ }^{40} \mathrm{~K}$ activity in the medicinal plants obtained from this study were compared with other published work in Table 2. 
Table 2. Comparison of the activity concentration of ${ }^{226} \mathrm{Ra}$, ${ }^{232} \mathrm{Th}$ and ${ }^{40} \mathrm{~K}$ in the medicinal plants from this study with those from other countries

\begin{tabular}{|c|c|c|c|c|c|}
\hline \multirow{2}{*}{ Reference } & \multirow{2}{*}{ Country } & \multirow{2}{*}{$\begin{array}{l}\text { Scientific name } \\
\text { of plant }\end{array}$} & \multicolumn{3}{|c|}{ Activity concentration $\left(\mathrm{Bqkg}^{-1}\right)$} \\
\hline & & & ${ }^{226} \mathrm{Ra}$ & ${ }^{232} \mathrm{Th}$ & ${ }^{40} \mathrm{~K}$ \\
\hline This study & Kars/Turkey & $\begin{array}{l}\text { Studied medici- } \\
\text { nal Plants }\end{array}$ & $16.39-32.76$ & $19.74-85.01$ & $736.91-1056.28$ \\
\hline \multirow{4}{*}{ (14) } & \multirow{4}{*}{ Serbia } & Urtica dioica & $14.4 \pm 1.7$ & $15.8 \pm 1.9$ & $761 \pm 9$ \\
\hline & & $\begin{array}{c}\text { Rosa } \\
\text { canina L. }\end{array}$ & $3.8 \pm 0.9$ & $7.3 \pm 1.7$ & $385 \pm 5$ \\
\hline & & $\begin{array}{c}\text { Matricaria } \\
\text { chamomilla L. }\end{array}$ & $28.6 \pm 2.6$ & $9.0 \pm 2.1$ & $917 \pm 8$ \\
\hline & & $\begin{array}{c}\text { Mentha } \\
\text { Iongifolia (L.) }\end{array}$ & $35.7 \pm 3.2$ & $13.9 \pm 1.7$ & $649 \pm 7$ \\
\hline \multirow{3}{*}{ (6) } & \multirow{3}{*}{ Egypt } & $\begin{array}{c}\text { Matricaria } \\
\text { chamomilla L. }\end{array}$ & $19.62 \pm 0.6$ & $11.71 \pm 0.4$ & $1170 \pm 36$ \\
\hline & & $\begin{array}{l}\text { Petroselinum } \\
\text { sativum }\end{array}$ & $42.85 \pm 1.5$ & $5.87 \pm 0.2$ & $933 \pm 29$ \\
\hline & & Thymus & $90.88 \pm 3.0$ & $15.68 \pm 0.3$ & $1003 \pm 31$ \\
\hline \multirow[b]{2}{*}{ (15) } & \multirow[b]{2}{*}{ Iraq } & Thymus & - & - & $587.0 \pm 44.5$ \\
\hline & & $\begin{array}{c}\text { Matricaria } \\
\text { chamomilla L. }\end{array}$ & - & - & $883.3 \pm 85.8$ \\
\hline \multirow{4}{*}{ (3) } & \multirow{4}{*}{ Italy } & $\begin{array}{c}\text { Mentha } \\
\text { Iongifolia (L.) }\end{array}$ & - & - & 814 \\
\hline & & Thymus & - & - & 615 \\
\hline & & $\begin{array}{c}\text { Matricaria } \\
\text { chamomilla L. }\end{array}$ & - & - & 1077 \\
\hline & & Rosa canina L. & - & - & 703 \\
\hline (2) & India & Citrus limonum & $6.08 \pm 0.73$ & $5.67 \pm 1.00$ & $1910.00 \pm 139.09$ \\
\hline
\end{tabular}

The radioactivity contents of various medicinal plants have been extensively studied in different parts of the world. The specific activities of the plants measured by some of these studies and the findings of this study were given in Table 2. As can be seen, our results are in good agreement with the literature. Table 2 shows the comparison of our results obtained in present study with other reports, the mean values of ${ }^{226} \mathrm{Ra},{ }^{232} \mathrm{Th}$ and ${ }^{40} \mathrm{~K}$ in urtica diocia are higher than the reported values in Serbia ${ }^{14}$.

In a study in Egypt conducted by Ahmed et al. (2010) in petroselium sativum and thymus plants, the average activity concentration values for ${ }^{226} \mathrm{Ra}$ were found to be 42 and 90,88 $\mathrm{Bqkg}^{-1}$, respectively. Their reported values are higher than reported values in this study for same medicinal plants ${ }^{6}$. 
In this study, the average radioactivity concentration of ${ }^{232} \mathrm{Th}$ in medicinal plants was found as $61.15 \mathrm{Bqkg}^{-1}$ which is much higher than previously reported in other countries ${ }^{2,6,14}$. Similarly, ${ }^{40} \mathrm{~K}$ concentrations in medicinal plants were higher than concentration in medicinal plants from other countries except India and Egypt ${ }^{2,6}$. These results can be explained may be due to a wide differences in the soil component which are normally directly dependent to the main rocks, the type of weathering processes, and also the content of the fertilizers used in the soil ${ }^{2}$.

The average values of activity concentrations of ${ }^{226} \mathrm{Ra},{ }^{232} \mathrm{Th}$ and ${ }^{40} \mathrm{~K}$ in medicinal plant were $22.66 \pm 3.5,61.03 \pm 4.3$, and $932.76 \pm 13.4 \mathrm{~Bq} \mathrm{~kg}^{-1}$ dry weight, respectively. These results are in good agreement with the published values of other countries. It is very important to determine the level of radioactivity concentrations in medicinal plant to ensure consumer safety. The obtained results provide useful information to carry out a dose assessment due to ingestion of these plants because people use traditional medicinal plants for healing various diseases. The results of this study provide initial values that may be useful in making regulations for radiation protection and in developing standards for the use of medicinal plants in making medicines by the appropriate authorities.

\section{ACKNOWLEDGEMENTS}

This study was supported as financial by Kafkas University Scientific Research Projects Coordinator ship (BAP 2017FM25). 


\section{REFERENCES}

1. Chan, K. Some Aspects of Toxic Contaminates in Herbal Medicine. Chemosphere. 20o3, 52, 1361-1371.

2. Chandrashekara, K.; Somashekarappa, H.M. Estimation of radionuclides concentration and average annual committed effective dose due to ingestion for some selected medicinal plants of South India. J. Rad. Res. Appl. Sci. 2016, 9, 68 -77

3. Desideri, D.; Meli, M.A.; Roselli, C. Natural and artificial radioactivity determination of some medicinal plants. J. Environ. Radioact. 2010, 101, 751-756.

4. Sussa, F.V.; Damatto, S. R.; Alencar, M. M.; Mazzilli, B. P.; Silva, Paulo S. C. Natural radioactivity determination in samples of Peperomia pellucida commonly used as a medicinal herb. $J$. Environ. Radioact. 2013, 116, 148-151.

5. Badran, H. M.; Sharshar, T.; Elnimer, T. Levels of ${ }^{137} \mathrm{Cs}$ and ${ }^{40} \mathrm{~K}$ in edible parts of some vegetables consumed in Egypt. J. Environ. Radioact. 2oo3, 67, 181-190.

6. Ahmed, F.; Daif, M. M.; El-Masry, N. M.; Abo-Elmagd, M. External and internal radiation exposure of herbal plants used in Egypt. Radiat. Eff. Def. Solids. 2010, 165, 65-71

7. UNSCEAR (United Nations Scientific Committee on the Effects of Atomic Radiation) Sources and Effects of Ionizing Radiation, United Nations Publication, 200o, New York, USA

8. Mukhammedov, S.; Tillaeva, K. Natural radioactivity of some medicinal plants. $J$ Nucl Radiat Phys. 2005, 1, 73-76

9. Tettey-Larbi, L.; Darko, E. O.; Schandorf, C.; Appiah, A. A. Natural radioactivity levels of some medicinal plants commonly used in Ghana. SpringerPlus. 2013; 2, 157

10. Fahad, S. M.; Abdin, M. J.; Hasan, M. M.; Rahman, M. O.; Islam, S.M.A.; Akramuzzaman, M. M.; Russell, M. Study of Elemental Profile of Some Medicinal Plants of Bangladesh. J. Nucl. Part. Phys. 2014, 4, 1-6.

11. Gezer, F.; Turhan, S..; Kurnaz, A.; Ufuktepe, Y. Radiometric characterization of zeolite minerals used in many industries and assessment of radiological risk. Appl. Radiat. Isotopes. 2019, 152, 57-63

12. Günay, O.; Eke, C. İstanbul-Sariyer İlçesindeki Bazi Toprak Örneklerinde Cs-137 Konsantrasyonun Belirlenmesi. KLU Müh. Fen Bilim. Dergisi. 2019, 5, 29-39

13. Bilgici Cengiz, G. Transfer factors of ${ }^{226} \mathrm{Ra},{ }^{232} \mathrm{Th}$ and ${ }^{40} \mathrm{~K}$ from soil to pasture-grass in the northeastern of Turkey. J. Radioanal. Nucl. Chem. 2019, 319, 83-89

14. Djelic, G.; Krstic, D.; Stajic, J. M.; Milenkovic, B.; Topuzovic, M.; Nikezic, D.; Vucic, D.; Zeremski, T.; Stankovic, M.; Kostic, D. Transfer factors of natural radionuclides and ${ }^{137} \mathrm{Cs}$ from soil to plants used in traditional medicine in central Serbia. $J$. Environ. Radioact. 2016, 158$159,81-88$

15. Najam LA, Tafiq NF, Kitah FH. Estimation of Natural Radioactivity of Some Medicinal or Herbal Plants Used in Iraq. Detection. 2015, 3, 1-7 